\title{
PENGELOLAAN POTENSI ALAM MELALUI APLIKASI TEKNOLOGI UNTUK MENINGKATKAN PRODUKTIVITAS MASYARAKAT
}

\author{
I.M. Astika ${ }^{1}$, M. Suarda ${ }^{2}$ I.G.K. Sukadana ${ }^{3}$, dan I.G.K. Dwijana ${ }^{4}$
}

\begin{abstract}
ABSTRAK
Peningkatan partisipasi masyarakat dalam pengelolaan potensi desa berbasis teknologi demi terwujudnya pembangunan desa berkelanjutan merupakan tema dari program KKN-PPM di desa Belok Sidan. Melalui beberapa program seperti: program kesehatan masyarakat, penyediaan air bersih melalui penerapan teknologi hydram, penerapan metode gravitasi pada system air bersih di tempekan Pucak Sari, penyuluhan sanitasi rumah tangga dan penyuluhan pola hidup bersih dan sehat pada anak-anak sekolah. Program yang berkaitan dengan lingkungan adalah penerapan teknologi sumur resapan dan biopori di pekarangan rumah penduduk dan kegiatan penghijauan dengan menanam kelapa daksina di areal tanah marginal dan daerah sumber air. Peningkatan produksi kopi bubuk melalui penerapan teknologi mesin pemecah kulit kopi basah. Metode yang diterapkan untuk mengatasi permasalahan masyarakat adalah: metode penyuluhan, pendampingan, gotong royong, penerapan teknologi tepat guna dan metode percontohan. Hasil pelaksanaan program: sistem air bersih metode pompa hydram dan gravitasi sudah terealisasi. Dari hasil evaluasi debit pemompaan 1.5 liter perdetik cukup untuk melayani 250 KK di dusun Punikit. Kegiatan PHBS sudah terlaksana dengan capaian 60 siswa SD di dusun Punikit. Kegiatan pelayanan kesehatan ternak capaiannya sekitar 160 ternak terlayani. Seratus pohon kelapa daksina telah ditanam diareal pura taman dan pura dalem. Kegiatan pendampingan usaha kopi bubuk dengan mesin pemecah kopi sudah beoperasi sesuai rencana dan beroperasi optimal. Kegiatan pembuatan kolam ikan air tawar sekaligus berfungsi sebagai rest point area wisata tracking sudah terlaksana dengan ditandai penebaran bibit ikan nila.
\end{abstract}

Kata Kunci : potensi desa, teknologi, produktivitas

\begin{abstract}
Increasing community participation in the management of technology-based village potentials for the realization of sustainable village development is the theme of the KKN-PPM program in the village of Belok Sidan. Through several programs such as: public health program, clean water supply through application of hydram technology, application of gravity method to clean water system in Pucak Sari, household sanitation extension and counseling clean and healthy lifestyle in school children. Environmental programs are the application of absorption and biopore technology in the home yard and reforestation activities by planting coconut in marginal land area and water source area. Increased production of coffee powder through the application of machine technology. The methods applied to overcome community problems are: counseling, mentoring, application of appropriate technology and pilot method. Results of program implementation: hydram system and gravity pump method has been realized. From the results of the evaluation of pumping discharge 1.5 liter per second enough to serve 250 families in the Punikit village. PHBS activities have been done with the achievement of 60 elementary students. Livestock health services activities reaches about 160 livestock served. One hundred coconut trees have been planted in the temple park and temple grounds. The business activities of coffee powder with coffee breaker machine have operated according to plan and operate optimally. Activities of making freshwater fish ponds as well as functioning as a tourist rest point area has been done with marked stocking of tilapia seeds.
\end{abstract}

Keywords : potential villages, technology, productivity

\footnotetext{
${ }^{1}$ Staf Pengajar, Program Studi Teknik Mesin, Fakultas Teknik, Universitas Udayana,imdastika @.yahoo.com 2,3,4 Staf Pengajar Program Studi Teknik Mesin, Fakultas Teknik Universitas Udayana
} 


\section{PENDAhUluan}

Desa Belok Sidan berada di kecamatan Petang kabupaten Badung, terdiri dari 8 dusun antara lain: dusun Punikit, dusun Sekarmukti Kaje, dusun Bon, dusun Lawak, dusun Belok, dusun Sidan, dusun Selantang dan dusun Punikit. Desa Belok Sidan merupakan desa yang terletak di daerah pegunungan, dengan jumlah penduduk sekitar 7500 jiwa. Luas wilayah desa Belok Sidan sekitar 8 $\mathrm{km}^{2}$, yang seluruhnya merupakan daerah pertanian dan perkebunan. $85 \%$ penduduk desa Belok Sidan bekerja sebagai petani, dan sisanya sebagai buruh, karyawan swasta dan PNS.

\subsection{Potensi desa}

Potensi yang belum sepenuhnya dikembangkan dan manfaatkan di desa Belok Sidan antra lain:

a. Potensi dibidang pertanian dan perkebunan. Hampir $100 \%$ wilayah desa Belok Sidan adalah daerah pertanian yang subur dan terbagi dalam subak basah sekitar $15 \%$ dan subak kering $85 \%$. Pertanian rakyat yang sangat cocok dikembangkan adalah produk yang berorientasi pasar atau berproduksi untuk dijual seperti asparagus, bunga gumitir, dll.

b. Potensi dibidang peternakan. Persediaan pakan ternak bukan merupakan permasalahan dalam pengembangan peternakan di desa Belok Sidan. Dilihat dari jumlah petani, 100\% juga merupakan peternak dengan jumlah ternak rata-rata 2-4 ekor sapi, 2-6 ekor babi dan rata-rata 510 ekor ayam kampung setiap KK. Dari 5\% wilayah pertanian tanaman basah (sawah) sistem perikanan air tawar memiliki potensi yang cukup besar dan sangat perlu untuk dikembangkan, seperti ikan nila, lele, dan ikan air tawar lainnya.

c. Potensi dibidang industri. Di Belok Sidan telah dikembangkan industri pariwisata agro yang sangat potensial karena ditopang oleh wilayah yang berbukit dan subur, segala jenis tanaman dapat tumbuh dengan baik. Terlihat dari potensi asparagus dan bunga gumitir yang memiliki prospek sangat bagus untuk dikelola dengan membentuk sebuah wadah yaitu kelompok tani atau koperasi.

d. Potensi dibidang sumber air. Desa Belok Sidan memiliki banyak sumber air bersih yang dapat dimanfaatkan untuk pertanian dan kebutuhan sehari-hari. Tetapi karena lokasi pemukiman penduduk desa Belok Sidan sebagian besar di lereng atau perbukitan menyebabkan pengelolaan sumber air untuk kebutuhan sehari-hari tidak optimal. Sehingga masyarakat yang tinggal di daerah perbukitan seperti di dusun Punikit dan dusun Bon sangat kesulitan untuk mendapatkan air bersih.

e. Potensi dibidang sosial budaya. Masyarakat desa Belok Sidan sangat bersahabat, ramah, dan memiliki etika sosial yang sangat tinggi, yang masih menerapkan pakem-pakem tradisional dalam menjalankan kehidupan dalam bermasyarakat.

f. Potensi dibidang energi. Dari aktivitas peternakan yang dijalankan masyarakat desa dengan jumlah ternak pada setiap KK, minimal 2 ekor sapi dan babi, dan aktivitas pengolahan kopi maka sangat berpotensi dekembangkan sistem energi baru dan terbarukan atau energi hijau dalam hal ini energi biogas sekala rumah tangga, dan briket sekam kopi. Sehingga masingmasing rumah tangga dapat menghasilkan energi untuk kebutuhan sehari-hari sehingga kelestarian alam dan hutan desa Belok Sidan dapat terjaga dan terpelihara.

\subsection{Permasalahan Masyarakat}

Dari hasil survey dan diskusi dengan kepala desa Belok Sidan dan kepala dusun Punikit dan Bon serta masyarakat, selain potensi desa seperti yang tertera diatas, desa Belok Sidan juga memiliki beberapa permasalahan antara lain.

a. Permasalahan dibidang pertanian dan perkebunan. Teknik pertanian yang masih tradisional, yang hanya mengandalkan cuaca sehingga produksi sangat tergantung pada musim. Disamping itu masih rendahnya pengetahuan masyarakat dalam mengembangkan teknologi pasca panen 
sehingga hasil pertanian banyak yang busuk pada saat produksi pertanian tinggi dan harga rendah.

b. Permasalahan dibidang peternakan. Produktivitas peternakan masyarakat sangat rendah, hal ini disebabkan oleh terbatasnya pengetahuan masyarakat tentang kesehatan ternak, kandang yang sehat, makan yang sehat, dan pengolahan pakan sehingga laju pertumbuhan ternak sangat lambat.

c. Permasalahan dibidang industri. Kurangnya pengetahuan masyarakat terhadap teknologi pengolahan dan pengeringan menyebabkan proses pengerjaan menjadi lambat dan produktivitas menjadi sangat rendah, terutama bila panen terjadi pada saat musim hujan.

d. Permasalahan dibidang kesehatan. Masyarakat yang bertempat tinggal di perbukitan seperti di dusun Punikit dan Bon sangat kesulitan untuk mendapatkan air bersih dalam memenuhi kebutuhan sehari-hari, sehingga sangat berpengaruh terhadap pola hidup masyarakat seperti mandi cuci dan kakus (MCK).

e. Permasalahan di bidang energi. Sebagian besar wilayah desa Belok Sidan berada di wilayah perbukitan, menyebabkan akses energi berupa LPG sangat kurang dan belum termanfaatkan dengan baik limbah dari kotoran ternak dan sampah serta limbah industri berupa kulit kopi untuk sumber energi pedesaan.

\section{METODE PELAKSANAAN}

Adapun metode yang dilakukan pada kegiatan KKN-PPM ini adalah

1. Metode sosialisasi program kepada masyarakat. Kegiatan ini bertujuan untuk memperkenalkan/mensosialisasikan program-program kegiatan yang dilaksanakan selama waktu KKN-PPM berlangsung dan untuk mendapatkan dukungan masyarakat sasaran.

2. Metode penyuluhan, tujuannya untuk memberikan pembekalan kepada masyarakat maksud, tujuan, cara-cara, serta manfaat dari kegiatan. Pada kegiatan ini menggunakan penyuluh dari institusi yang berkompoten seperti dari Dekopinda-Bali, Dinas Kesehatan.

3. Metode pendampingan, bersama dengan kelompok sasaran melaksanakan program kerja.

4. Metode percontohan, memberikan model atau prototipe kepada kelompok sasaran.

\section{HASIL DAN PEMBAHASAN}

\subsection{Kegiatan perkenalan mahasiswa ke desa}

Pada kegiatan ini dilaksanakan acara perkenalan, mencari informasi tentang Desa Belok Sidan dan menyampaikan rencana yang akan dilaksanakan pada program KKN-PPM dari Udayana.

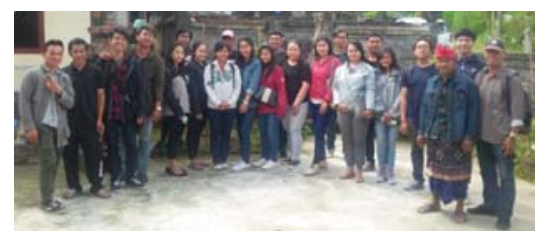

Gambar 1. Perkenalan mahasiswa KKN-PPM dengan aparat Desa Belok Sidan

\subsection{Serah Terima Mahasiswa Di Desa}

Pada tanggal 23 Juli 2016 dilaksanakan penyerahan mahasiswa peserta KKN-PPM kepada Kepala Desa Belok Sidan dan masyarakat Dusun Punikit. 


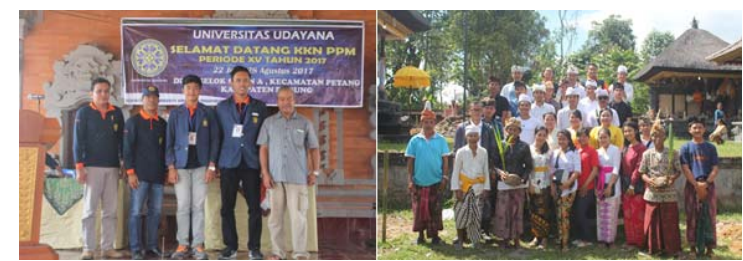

Gambar 2. Serah terima mahasiswa dengan bapak Kepala Desa Belok Sidan dan Kepala Dusun Punikit

Setelah mahasiswa peserta KKN-PPM diterima oleh Bapak Kepala Desa Belok Sidan, selanjutnaya mahasiswa diserahkan kepada Kepala Dusun Punikit. Karena dusun Punikit menjadi pusat aktifitas mahasiswa selama 5 minggu.

\subsection{Kegiatan pendampingan sistem air bersih metode gravitasi}

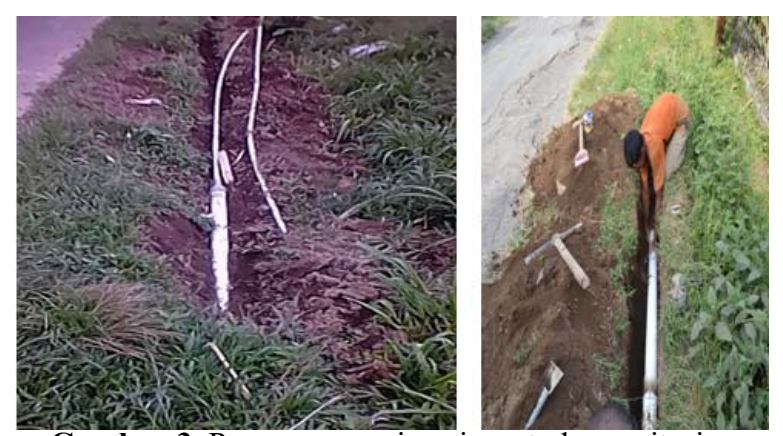

Gambar 3. Pemasangan pipa air metode gravitasi

Hasil yang telah dicapai pada kegiatan ini, telah terwujudnya sistem air bersih melalui penerapan teknologi pompa Hydram. Dan sistem sudah bekerja dengan baik dengan masyarakat yang terlayani sebanyak $25 \mathrm{KK}$.

\subsection{Kegiatan penyuluhan dan pendampingan pola hidup bersih dan sehat}
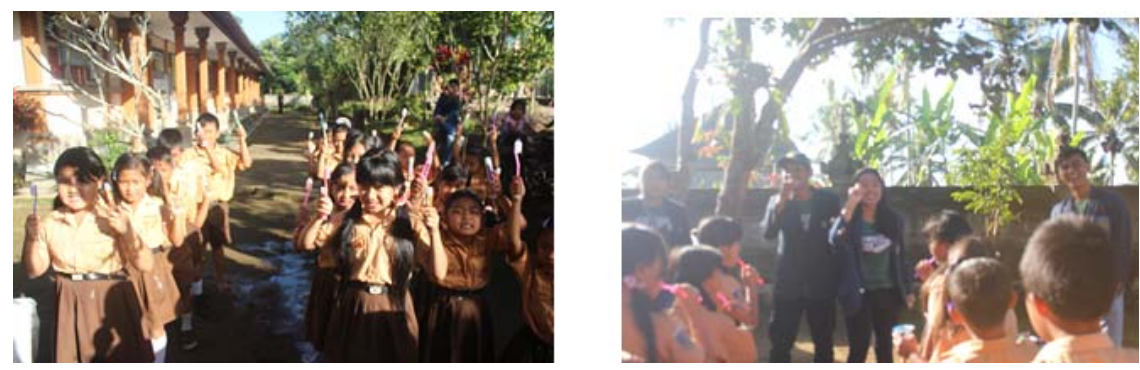

Gambar 4. Kegiatan penyuluhan dan pendampingan pola hidup dan sehat

Kegiatan PHBS diperuntukan kepada anak Sekolah Dasar 6 Belok/Sidan di dusun Punikit. Sejumlah 60 orang siswa kelas 1 sampai kelas 6 diberikan penyuluhan dan pelatihan tentang bagaimana cuci tangan yang bersih, bagaimana sikat gigi yang benar, bagaimana membawa tas yang baik. Pada kegiatan ini juga dibagikan perlengkapan sikat gigi dan sabun kepada 60 siswa SD dan anak anak lainnya yang hadir. 


\subsection{Penyuluhan dan Pelayanan Kesehatan Ternak}
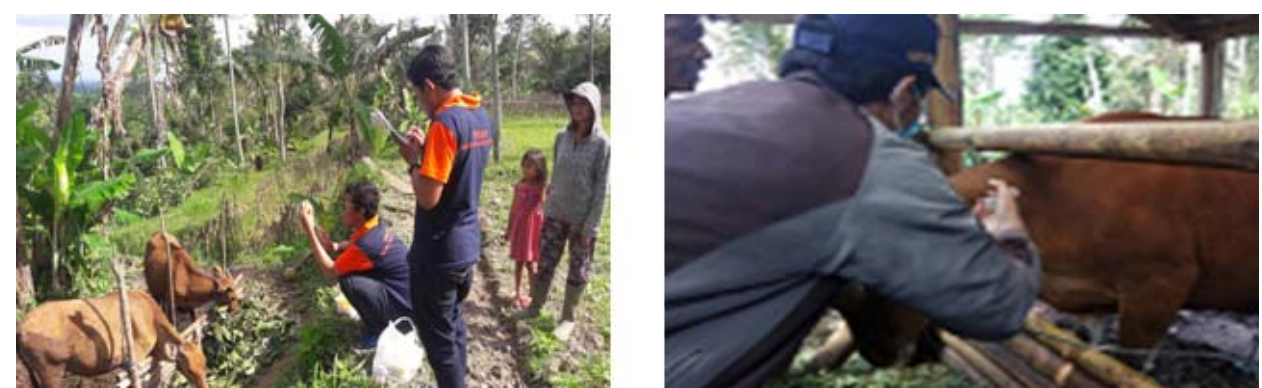

Gambar 5. Pelayanan kesehatan ternak

Kegiatan pelayanan kesehatan ternak dilaksanakan oleh mahasiswa dengan target layanan 100 ekor. Pelaksanaan kegiatan langsung pada kandang ternak baik kandang sapi maupun kandang babi. Pada kegiatan ini ternak diberikan vitamin, obat cacing, obat gatal kulit dan vaksin. Untuk peternak diberikan penyuluhan tentang cara beternak yang sehat, seperti kandang yang sehat, cara membuat pakan yang sehat dengan metode silase.

\subsection{Pendampingan Kelompok Industri Kopi Bubuk}

Pembuatan mesin pemecah kopi basah ini atas hasil survey dan permohonan kelompok kerja koperasi untuk dilakukan modifikasi terhadap mesin pemecah kopi yang ada. Permasalahan mesin yang ada yaitu hasil pemecah yang tidak maksimal, sebagian besar kopi menjadi hancur hal ini disebabkan oleh putran yang sangat tinggi.

Maka kelompok KKN-PPM UNUD merancang ulang mesin pemecah kopi. Dengan melakukan penggantian terhadap beberapa komponen seperti motor putaran rendah, system transmisi dll. Hasil dari kegiatan ini desain mesin pemecah kopi dengan putaran $60 \mathrm{rpm}$. Dari uji coba hasilnya cukup memuaskan. Jumlah kopi yang rusak/hancur sekitar 1 persen.

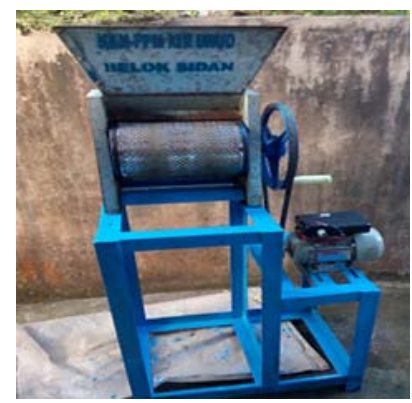

Gambar 6. Mesin pemecah kopi 


\subsection{Program Penghijauan Di Daerah Sumber Air Dan Daerah Perbukitan}

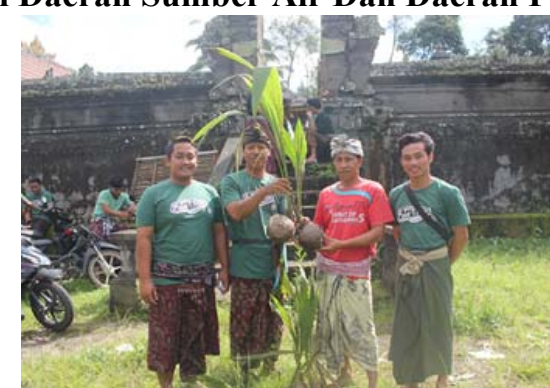

Gambar 7. Penghijauan 100 kelapa daksina

Kegiatan penghijauan ini difokuskan di dusun Punikit pada daerah lereng dan daerah dekat sumber air. Pada program penghijauan ini ditanan 100 pohon kelapa daksina.

\subsection{Program penataan rest point area wisata tracking/penataan pura taman}
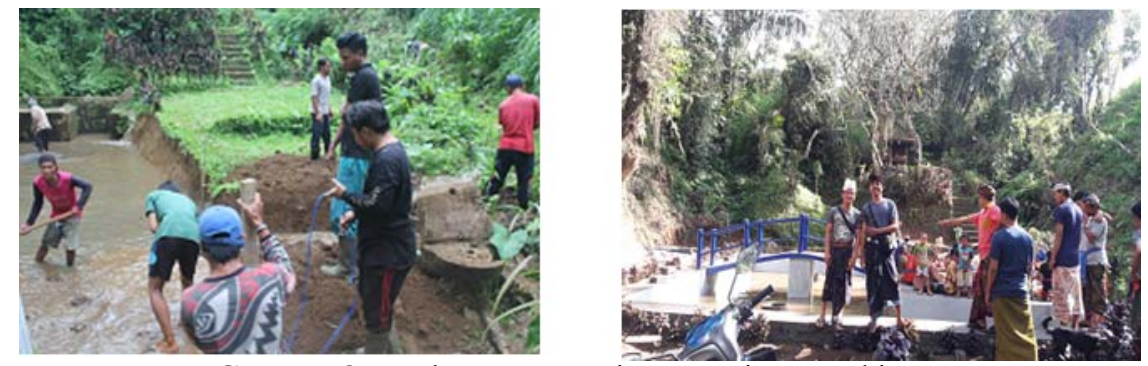

Gambar 8. Pembuatan rest point area wisata tracking

Hasil kegiatan ini yaitu taman dan rest point area yang serta berfungsi sebagai kolam ikan air tawar sudah terealisasi.

\subsection{Program bantu}
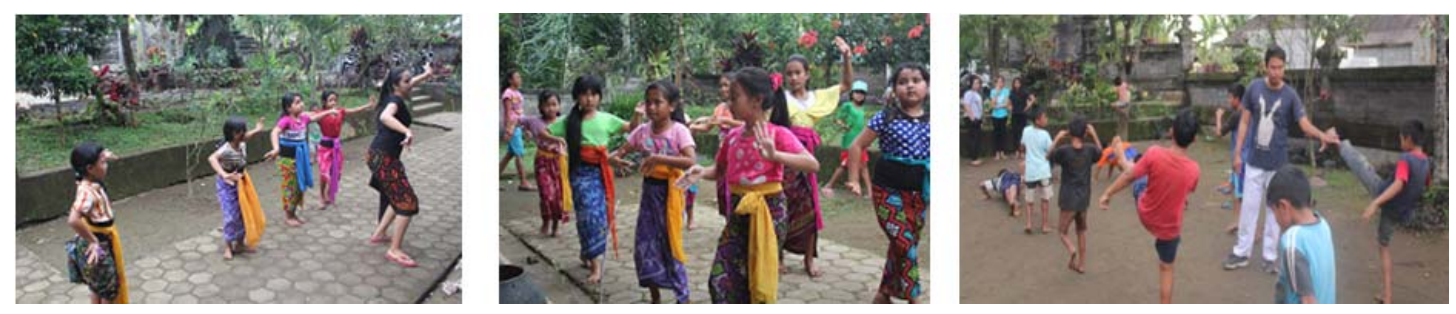

Gambar 9. Pendampingan pelajaran tari bali dan bela diri kepada anak anak

\section{KESIMPULAN DAN SARAN}

Adapun yang dapat disimpulkan dalam kegiatan ini adalah:

1. Sistem air bersih metode pompa hydram metode gravitasi sudah terealisasi. Dari hasil evaluasi debit pemompaan 0.4 liter perdetik cukup untuk melayani 25 KK di tempekan Puncak Sari

2. Kegiatan PHBS sudah terlaksana dengan capaian 60 siswa SD 6 Belok Sidan

3. Kegiatan pelayanan kesehatan ternak, capaiannya sekitar 160 ternak terlayani

4. Kegiatan penghijauan, 100 pohon kelapa daksina telah ditanam di areal sumber air dan di areal kawasan suci pura. 
5. Kegiatan pendampingan usaha kopi bubuk, mesin pemecah kopi sudah beoperasi dengan optimal.

6. Pembuatan rest point area wisata tracking yang sekaligus berfungsi sebagai tempat budidaya ikan air tawar dan kolam pancing sudah terlaksana.

\section{UCAPAN TERIMAKASIH}

Tim Pengabdian mengucapkan terima kasih kepada Direktorat Riset dan Pengabdian Masyarakat Direktorat Jenderal Penguatan Riset dan Pengembangan Kementerian Riset, Teknologi dan Pendidikan Tinggi yang telah mendanai pengabdian ini melalui skim KKN-PPM tahun 2017 sesuai dengan Kontrak Pengabdian Kepada Masyarakat Nomor: 416.39/UN14.4.A/PM/2017, tanggal 30 Maret 2017.

\section{DAFTAR PUSTAKA}

Sekretariat daerah kabupaten Badung, 2015, "Rencana program jangka menengah daerah kabupaten Badung", Badung

Fakultas Teknik UNUD, 2013, Buku pedoman akademik Fakultas Teknik Universitas Udayana, Bali.

Direktorat penelitian dan pengabdian kepada masyarakat direktorat jenderal pendidikan tinggi kementerian pendidikan dan kebudayaan, 2013, "Panduan pelaksanaan penelitian dan pengabdian kepada masyarakat di perguruan tinggi", edisi IX, Jakarta.

Direktorat penelitian dan pengabdian kepada masyarakat direktorat jenderal pendidikan tinggi kementerian pendidikan dan kebudayaan, 2013, "Panduan pelaksanaan hibah kuliah kerja nyata pembelajaran pemberdayaan masyarakat (KKN-PPM)", Jakarta. 